\title{
IMPACT OF AFRICAN FREE TRADE POLICY (AGREEMENT) ON THE SOCIO-ECONOMIC DEVELOPMENT OF NIGERIA
}

\author{
Chika P. Imoagwu, \\ Joan N. Ozoh, \\ Chinwe M. Madueke, \\ Chidinma C. Mbah ${ }^{\mathrm{i}}$ \\ Department of Economics, \\ Nnamdi Azikiwe University, Awka, \\ Anambra State, Nigeria
}

\section{Abstract:}

The signing of the agreement that established the African Continental Free Trade Area (AfCFTA) in the year 2019 is believed to be an African-based growth strategy that is selfreliant and is expected to be the world's largest free trade area after the World Trade Organization (WTO). The agreement is an attestation to the fact that African countries cannot continue to rely solely on the global trading system and global economy of the world economic powers, probably because they are increasingly becoming unpredictable. However, there is an assumption that the aggregate consumer and business spending on the continent could rise if AfCFTA is implemented successfully. This assumption therefore calls for a research like this to evaluate the likely economic impacts of the free trade agreement on different African countries particularly Nigeria which is the giant of Africa and the focus of this study. To achieve the objectives of the study, descriptive statistical approach was utilized to examine how the AfCFTA could contribute particularly on poverty reduction and Nigeria has been struggling for many decades to reduce poverty. These variables were considered: household income, illiteracy level, unemployment level and access to health care. The results of the analyses revealed that the AfCFTA could be slightly beneficial to Nigeria as it would improve the efficiency of the factors of production and product markets thereby enhancing household income generation, reducing the level of illiteracy, unemployment and increasing access to good health, efficient resource allocation and improved industry competitiveness which was expected to help Nigeria record significant reduction in poverty level and increase in economic development. In the light of these findings, the study recommends that government should then design proactive strategies that would reap the full benefits of AfCFTA such as engaging the private sector in identifying receptive and risk surrounding their sectors and paying more attention to the development of the service

iCorrespondence: email cp.imoagwu@unizik.edu.ng, ㅆn.ozoh@unizik.edu.ng,

cm.madueke@unizik.edu.ng, cc.mbah@unizik.edu.ng 
sector etc. The study has potential limitations such as unavailability of recent data. To tackle this limitation, the study adopted the 2019 survey data on pillars of measuring human development index by World Bank to address the quality of the findings, and research question.

JEL: F10, H13, O10

Keywords: free trade, policy, agreement, poverty, socio-economic development, scenario analysis

\section{Introduction}

After the disappointing outcome of the World Trade Organisation (WTO) (References) and the uncertainty surrounding its multilateralism ideology (Dent, 2010), many countries resorted to Preferential Trade Agreement (PTA), Bilateral Agreement, Regional Agreement, and Continental Agreement, which is why there has been increasing number of Free Trade Agreements (FTAs) around the world since the end of the Gulf War (Bhattacharya \& Das, 2014, Dent, 2010, Pant, 2010). There were only 16 FTAs in the world in 1990 (Dent, 2010). Baier, et al., (2019) revealed that the number of new trade agreements signed since 1986 is more than 350. This development threatened the success of the General Agreement on Tariffs and Trade (GATT), despite the fact the global tariffs were at historic low around the world except in South Asia (Pant, 2010).

A common objective of FTA is economic integration among member countries/regions (Baier, Yotov \& Zylkin, 2019). Although economic integration is beyond mere tariff reduction or elimination (Baier, et al., 2019), tariff and non-tariff measures are usually used to promote intra-trade among member countries (Perera, 2009). Proponents of FTA argue that it is a catalyst of accelerated economic growth (Awad, 2019) and an important instrument of poverty alleviation (Jagdambe \& Mouzam, 2019). Most FTAs promote agriculture by expanding the market for agricultural produce. This tends to increase agricultural production thereby helping to reduce the problem of food insecurity (Jagdambe \& Mouzam, 2019). Besides, it enhances allocative efficiency as each member country concentrate on the products which they have comparative advantage (Awad, 2019).

Developing countries are embracing FT As among themselves because they believe that it would help to resolve the challenges they face when trading with developed countries in terms of market access for agricultural trade, dumping, absence of reciprocal tariff concessions and so on (Jagdambe \& Mouzam, 2019). Awad (2019) revealed that are 17 regional trade blocs currently in Africa with 8 of them recognised by the African Union. Presently, the largest FTA on the continent is the African Continental Free Trade Agreement (AfCFTA) (Signé \& van der Ven, 2019). It was brokered by the African Union (AU) with the aim of boosting intra-Africa trade through the removal of tariffs on most goods thereby allowing free movement of commodities, goods, and services across the 
continent. United Nations Economic Commission for Africa (UNECA) predicted that successful implementation of the agreement would increase intra-Africa trade by 15 to 25\% (Signé \& van der Ven, 2019).

\subsection{Statement of the Problem}

Although the debate over the effectiveness of Free Trade Agreements (FTAs) in reducing poverty, improving social welfare, and stimulating economic development is far from over (Bene, et al., 2010), many proponents of free trade still believe that free trade plays a crucial role in the attainment of these macro-economic objectives. However, the recent shocking Brexit (Mold, 2018), and withdrawal of the United States (US) from the TransPacific Partnership (TPP) (Palit, 2017) is an indication that not all FTA may be beneficial and as such, desirable. One of the negative consequences of FTAs is that it leads to trade diversion, which is caused by preferential tariffs reduction (Harilal, 2012).

However, it is believed that the AfCFTA would enhance manufacturing and industrial development, tourism, intra-African cooperation, and economic transformation in Africa (Signé \& van der Ven, 2019), there are some reservations over what Nigeria stands to benefit from the agreement. With a nominal GDP of US\$376 million, which is about $17 \%$ of Africa's GDP, Nigeria is the largest economy in the continent. It has a huge market with a population of over 200 million people. The country has vast landscape, and blessed with enormous natural resources including oil. With all these indices, the question that begs for answer is: does Nigeria stand to derive any significant benefit from the AfCFTA?

The aim of this study is to assess the socio-economic implications of the AfCFTA for Nigeria. The specific objectives of this study are stated below:

1) To examine the potency of the AfCFTA in contributing to poverty alleviation in Nigeria;

2) To investigate the likely impact of AfCFTA on social development of Nigeria;

3) To conduct an econometric analysis of the likely impact of AfCFTA on economic growth and development of Nigeria.

\section{Literature Review}

\subsection{Conceptual Framework and Theoretical Review}

FTA is an element of trade liberalisation. It seeks to promote economies integration through trade. FTA can be defined as an undertaking by signatory countries in which they agreed to remove the barriers of trade between them (Dent, 2010). The essence of FTA is to facilitate trade among member countries through the removal of tariff and nontariff barriers (Perera, 2009). The importance of trade among countries as an engine of growth has been long acknowledged. Theoretical justification for trade relations is discussed under classical theories, and modern theories of trade. 


\subsection{Classical Theories of Trade}

The two main classical theories that championed free trade as an avenue to achieve production efficiency on global level are Adam Smith's theory of absolute advantage, and David Richardo's theory of comparative advantage (Sen, 2010). Although both theories have their limitations, Richardo's theory of comparative advantage is more realistic than Adam Smith's theory of absolute advantage (Sen, 2010). According to Adams Smith, the wealth of nations would be increased if there is free trade among countries (Terzea, 2016) as opposed to mercantilist policies of protection (Sen, 2010). He advocates for specialisation in production such that each country focuses on goods and services that they have competitive advantage over others (Terzea, 2016). However, Smith did not consider factor cost in determining the competitiveness of a country. David Ricardo developed further the theory of free trade introduced by Adam Smith by the inclusion of cost calculation in the determination of countries' competitiveness (Sen, 2010). Although, he considered labour cost, he was aware of the introduction of machinery in the production process on a large scale (Sen, 2010). His idea of free trade culminated into the formulation of theory of comparative advantage in which states that a country should specialise in the production of the goods it has comparative cost advantage over others. It is David Richardo's theory of comparative advantage and not Adams Smith's theory of absolute advantage that promotes mutual gains among trading countries (Sen, 2010).

\subsection{Modern Theories of Trade}

The most popular and relevant modern theory of trade is Heckscher-Ohlin theory. It was developed by two Swedish economists, Eli Heckscher and his student Bertil Ohlin (Lam, 2015). It is widely regarded as the greatest contribution to international trade (Subasat, 2003). It is a natural extension and improvement of Ricardo theory of international trade. Unlike Richardo's theory that postulates differences in production technologies between countries, Heckscher-Ohlin model assumes that production technologies are the same (Lam, 2015). The underlying assumptions of the theory include but not limited to: (1) free international mobility of commodities, (2) domestic mobility and international immobility of factors, (3) application of same production technology by all countries, (4) tastes are the same in all countries, (5) presence of economies of scale, (6) absence of transportation cost, (7) existence of perfect competition in all market (Subasat, 2003). The theory states that capital-abundant country should export a capital-intensive good while labour-abundant country should export a labour-intensive good (Subasat, 2003; Lam, 2015). In essence countries will produce and export the commodity on which they have low relative factor cost and import the commodity on which they have high relative factor cost.

\subsection{Empirical Review}

Several studies have been conducted to examine the impact of various FTAs signed around the world. 


\subsubsection{Impact of Free Trade Agreement on Poverty Reduction}

Liyanaarachchi, Naranpanawa and Bandara (2016) also employed Computable General Equilibrium (CGE), and micro-simulation model to analyse the effects of trade liberalisation on income distribution and poverty in Sri Lanka. It was found that a $100 \%$ tariff cut without complementary fiscal policy adjustments would lead to increase in economic growth, which would lead to poverty reduction both in the short-run and longrun. However, if the tariff cut is accompanied with fiscal policy adjustments, the impact on poverty was found to be mixed. Also, Maurizio and Niimi (2009) conducted a study to investigate the poverty effects of the Dominican Republic-Central American Free Trade Agreement (DR-CAFTA) between the United States; five Central American countries, which include: Costa Rica, El Salvador, Guatemala, Honduras, and Nicaragua; and the Dominican Republic. They applied general equilibrium macro model to examine the price effects and micro module to examine the impact of the price changes on real income levels of individual household of various trade reform scenarios in Nicaragua using simulation analysis. Although it was found that the impact of the DR-CAFTA on poverty is not too large, it's spread across households is significant. Ezeanyeji and Ozughalu (2014) points out that Nigeria is plagued with pervasive poverty, high level of underdevelopment, poor performance of the manufacturing sector and poor level of competitiveness, among others. Reduction of poverty is the most difficult challenges facing any country in the developing world, where on the average, majority of the populationare considered poor. Poverty is a disease which can be dehumanizing to man. It is a dreaded condition which tends to restrict people from socio - economic opportunities (Ezeanyeji, Imoagwu \& Ejefobihi, 2019).

Castilho, Menendez and Sztulman (2012) investigated the impact of trade liberalisation and integration into world economy on households' poverty and income inequality in Brazil using econometric tools. Although, it was found that rising exports exposure lowered poverty and income inequality at the state level, import penetration worsened poverty and income inequality. In the same vein, Bene, et al., (2010) applied Ordinary Least Square (OLS) and Two-Stage Least Square (2SLS) regression analysis to investigate the potential impact of international fish market on the economic and human development (poverty reduction) in sub-Saharan Africa using data of forty-seven (47) countries. The development indices used in the analysis are: malnutrition prevalence, mean monthly per capita income, and per capita GDP. It was found that there is no clear positive or negative effect international fish market on poverty.

\subsubsection{Impact of Free Trade Agreement on Social Welfare}

Siriwardanw and Yang (2007) examined the welfare implications of the Free Trade Agreement (FTA) between India and Bangladesh through CGE model using the GTAP model. The analysis was done through evaluation of the macro-economic and trade performance as well as sectoral changes under the India-Bangladesh FTA. The results of analyses showed that the bilateral trade liberalisation between the two countries would lead to welfare gains in both countries as a result of improved allocation efficiency and 
endowment effects. However, the terms of trade effects improved the welfare outcomes for India only. Also, Khan, Mehmood, Zakaria and ul Husnain (2018) evaluated the economic impact of the Pakistan-Malaysia FTA under two scenarios of FTA tariff structure and removal of non-tariff barriers using a global static Computable General Equilibrium (CGE) based on MyGTAP (Global Trade Analysis Project) model. The study sought to investigate the impact of the agreement on economic growth, production, trade, wages, investment and household income. It was found that the FTA had higher positive impact on household income under the non-tariff removal scenario and it keeps increasing systematically as the income level increases with few exemptions. Khan, et al., (2018) conclude that FTA could be more beneficial to both countries if they renegotiate the current agreement to get same tariff concession.

Kitwiwattanachai, et al., (2010) applied a modified version of the standard Computable General Equilibrium (CGE) model in which unemployment was incorporated into the model in order to analyse the economic effects of four East Asian Free Trade Area (FTA) options i.e. East-Asia multilateral agreement, ASEAN-China, ASEAN-Japan, and ASEAN-Korea. The analysis concentrated on 14 countries and regions, 14 tradeable sectors, and three factors i.e. skilled, unskilled, and capital which were assumed to be homogenous. It was found that the member countries of the FTAs would witness welfare gains while non-member countries would lose. However, the East-Asia FTA multilateral agreement has highest welfare gain. Similarly, Jagdambe and Mouzam (2019) applied partial equilibrium model to investigate the trade diversion effect, revenue effect, and welfare effect of ASEAN-India Free Trade Agreement (tariff reduction/elimination) with focus on India's special products categories, namely, coffee, tea and pepper. It was found that trade diversion as a result of tariff reduction under the FTA led to increase in importation of cheaper goods, which consequently increased consumers' gains thereby improving their welfare. Again, Awad (2019) employed dynamic OLS, and a non-parametric technique to investigate the environmental impact of intra-Africa trade using panel dataset of 46 African countries over the period 19902017. To do this, the relationship between growth, and energy consumption was examined using two measurements of environmental pollutants, namely CO2 and MP10. The results of both analyses suggest that intra-Africa trade actually improved environmental quality in Africa. Although it was found that increased production activities led to increased energy consumption, which caused more pollution, it was only marginal.

\subsubsection{Impact of Free Trade policy on Economic Development}

Most of the studies reviewed investigated the impact of FTA on economic growth and development through the trade channel. Virtually all studies revealed that FTA would boost trade, which would consequently contribute to economicgrowth and development. For instance, against the backdrop of the importance of South-South regional cooperation, Bhattacharya and Das (2014) applied a stochastic frontier gravity model to analyse the relationship between trade and development goals in the context of the South 
Asian Association for Regional Cooperation (SAARC). It was found that the regional cooperation has the potential to boost trade which would close development gap through growth gains that accrue from trade and investment spillovers, exchange of skills and knowledge. Ezeanyeji and Obi (2019) established the impact of interest rate deregulation on saving mobilization in Nigeria from 1981 to 2017. The Augmented Dickey-Fuller (ADF) test, co-integration test and Error Correction Model (ECM), were employed in the analysis. The research findings revealed that interest rate and Government policy, proxied by dummy variable, is negative and statistically insignificant on savings mobilization. Also, gross capital formation, inflation rate and real GDP are positive but statistically insignificant on savings mobilization in Nigeria. Also, Kien (2009) employed the Hausman-Taylor (HT) estimation technique to examine the pattern of exports flow of countries in the ASEAN Free Trade Area (AFTA) using panel data of thirty-nine countries spanning from 1988 to 2002 based on a gravity model. It was found that the AFTA enhanced intra-trade between members as well as encouraged members to trade with non-member outside of the region. Furthermore, the increased trade creation was also accompanied by increase in the GDP, though it was more proportional.

Kpomblekou and Wonyra (2020) employed the maximum likelihood with fixed effects estimation method to evaluate the spatial diffusion of international trade among countries in the West African Economic and Monetary Union (WAEMU). Panel data of the eight member countries over the period 1960-2015 were analysed with the aim of assessing the economic gains of the union. The results of analyses showed that economic and social interactions among member countries enhance spatial diffusion of international trade among which consequently yield economic gains such as: increase in Gross Domestic Product (GDP), higher gross capital formation, increased public spending and so on. Similarly, Ha, et al., (2017) conducted simulation analysis of the free trade scenario of the Trans-Pacific Partnership (TPP) with focus on its impact on the industrial and economic performance of Vietnam. The results of the analyses revealed that the country would benefit from the implementation of the regional FTA as its GDP growth rate was expected to increase from $0.12 \%$ to $0.72 \%$ between 2015 and 2019 and even further from $0.87 \%$ to $1.45 \%$ between 2020 and 2024, which is about $50 \%$ GDP growth rate. Again, Mold and Mukwaya (2016) employed the Global Trade Analysis Project (GTAP) Computable General Equilibrium (CGE) model to appraise the economic implications of the proposed formation of a Tripartite Free Trade Area (TFTA) between three existing regional economic communities - the East African Community (EAC), the Common Market for Eastern and Southern Africa (COMESA), and the Southern African Development Community (SADC) involving 26 African countries. It was found that the trade agreement would spur industrial production especially manufacturing such as light and heavy manufacturing, and food processing.

\subsection{Research Gap}

The ACFTA is the first major continental FTA in the continent that has attracted so much interest and attention. As at July 2019, 54 out of the 55 African countries had signed the 
agreement on the hope that it would enhance the competitiveness of member countries in Africa and the global market. However, the initial reluctance of Nigerian government to join the free trade suggests that it may not in be interest of the country. This is a merely notion and needs to be investigated empirically. To the best of my knowledge, there is no study that has been conducted to appraise the likely implications of the ACFTA for Nigeria. This study fills this gap by applying econometric tools and simulation analysis to examine the likely impact of the FTA on poverty alleviation, household welfare, and economic development of Nigeria.

\section{Research Methodology}

\subsection{Theoretical Framework}

The theoretical framework underlying this study is the Heckscher-Ohlin theory. Although some of the assumptions of this theory are not realistic, it is the most ideal theory that can used to examine the reality of FTA in the context of international trade. The theory justifies the need for country to specialise as advocated by Adams Smith and David Ricardo in order to improve their productive efficiency. When countries agree to form FTA, the market is liberalised and goods are allowed to being moved freely from one member country to another. This would encourage competition among manufacturers who will in turn develop and strengthen their competitive advantage. The main source of competitive advantage as advocated by Heckscher-Ohlin theory is cost efficiency. In line with this theoretical explanation, it is expected that the AfCFTA would compel member countries to focus on the production and export of commodities and goods on which they have competitive advantage. It is expected that it would increase investment, stimulate production, and improve resource allocation. Subsequently, these would lead to socio-economic development through improved social welfare, reduced incidence of poverty, and increased economic growth and development.

\subsection{Model Specification}

Three models were formulated for this study. They were formed based on the HeckscherOhlin theory in order to answer the three research questions stated in this study. The first model intends to evaluate the impact of Africa intra-trade on poverty alleviation in Nigeria. The second model seeks to examine the effect of Africa intra-trade on household welfare; and the third model investigates the impact of Africa intra-trade on the economic growth and development of Nigeria. The three models are stated below thus:

\section{Model One:}

The first model seeks to examine the potency of the AfCFTA in contributing to poverty alleviation in Nigeria. The modified model of Liyanaarachchi, et al., (2016) was to capture objective one (1) of this study; the following functional model were developed thus;

$\mathrm{PH}=f(\mathrm{EXR}, \mathrm{TOI}, \mathrm{PH}-1)$ 
The estimating form of equation (1) above is represented as;

$\mathrm{PH}_{\mathrm{t}}=\mathrm{a}_{0}+\mathrm{a}_{1} \mathrm{EXR}_{\mathrm{t}-1}+\mathrm{a}_{2} \mathrm{TOI}_{\mathrm{t}-1}+\mathrm{a}_{3} \mathrm{PH}_{\mathrm{t}-1}+\mu_{\mathrm{t}}$

Where:

$\mathrm{PH}_{\mathrm{t}}=$ Poverty headcount ratio at $\$ 1.90$ a day (2011 PPP) (\% of population) for current year $\mathrm{PH}_{\mathrm{t}-1}=$ Poverty headcount ratio at $\$ 1.90$ a day (2011 PPP) (\% of population) for previous year $\mathrm{EXR}_{\mathrm{t}-1}=$ Official exchange rate (LCU per US\$, period average) for previous year $\mathrm{TOI}_{\mathrm{t}-1}=$ Africa Trade Openness Indicator $\left.\left\{\left(\operatorname{aexp}_{\mathrm{t}}+\operatorname{aimp}_{\mathrm{t}}\right) / \text { agdp }\right\}_{\mathrm{t}}\right\}$ for previous year $\mathrm{a}_{0}=$ Constant $\mathrm{a}_{1}, \mathrm{a}_{2}, \mathrm{a}_{3}$-arethe parameters.

$\mu$ is error term

\section{Model Two:}

The second model aims to investigate the likely impact of AfCFTA on social development of Nigeria. The study has employed and modified the model formulated by Siriwardanw and Yang (2007) to capture objective two (2) of this study; the following functional model was developed thus;

$\mathrm{LE}=f(\mathrm{EXR}, \mathrm{TOI}, \mathrm{LE}-1)$

Equation 3 can be represented explicitly as;

$\mathrm{LE}_{\mathrm{t}}=\alpha_{0}+\alpha_{1} \mathrm{EXR}_{\mathrm{t}-1}+\alpha_{2} \mathrm{TOI}_{\mathrm{t}-1}+\alpha_{3} \mathrm{LE}_{\mathrm{t}-1}+\mu_{\mathrm{t}}$

Where:

$l_{t}=$ Life expectancy at birth, total (years) for current year

$l_{\mathrm{t}-1}=$ Life expectancy at birth, total (years) for previous year

exrt-1 = Official exchange rate (LCU per US\$, period average) for previous year

toit-1 $=$ Africa Trade Openness Indicator $\left\{\left(\operatorname{aexp}_{t}+\operatorname{aimp}_{\mathrm{t}}\right) /\right.$ agd $\left.\mathrm{p}_{\mathrm{t}}\right\}$ for previous year

$\alpha_{0}$-Constant

$\alpha_{1}, \alpha_{2}, \alpha_{3}$ - are the parameters.

$\mu$ is error term

\section{Model Three:}

The third model aims to probe the likely impact of AfCFTA on economic growth and development of Nigeria. The model from the work of Bhattacharya and Das (2014) were adopted and modified to capture objective three (3) of this study; the following functional model was developed thus;

$\mathrm{G}=f(\mathrm{EXR}, \mathrm{TOI}, \mathrm{G}-1)$

Equation 5 can be represented explicitly as; 
Where:

$\mathrm{Gt}_{\mathrm{t}}=\mathrm{GDP}$ growth (annual \%) for current year

$\mathrm{Gt}-1=\mathrm{GDP}$ growth (annual \%) for previous year

$\mathrm{EXR}_{\mathrm{t}-1}=$ Official exchange rate (LCU per US\$, period average) for previous year

TOI $_{t-1}=$ Africa Trade Openness Indicator $\left\{\left(\operatorname{aexp}_{t}+\operatorname{aimp}_{\mathrm{t}}\right) / \operatorname{agdp}_{\mathrm{t}}\right\}$ for previous year

$\mathrm{C} 0=$ Constant

$\mathrm{C}_{1}, \mathrm{C}_{2}, \mathrm{C}_{3}=$ are the parameters.

$\mu=$ error term

\subsection{Method of Data Analysis and Sources of Data}

The method of data analysis employed in this study is quantitative data analysis method. It involves the use of data to quantify the size of intra-trade in Africa and to examine the relationship between the variables that correlate. Both regression analysis and simulation analysis were used to examine the likely impact of the AfCFTA on Nigeria's socioeconomic development.

The estimation technique used in this study is based on the co-integration theory. Augmented Dickey-Fuller (ADF) test, Johansen VAR-based co-integration technique, Vector Error Correction Model(VECM), and Vector Auto-Regression(VAR) system were applied. The time series properties of the data were first analysed to correct any serial correlation by using their differenced values. Then, Johansen co-integration tests were conducted to know whether to conduct to run Vector Error Correction Model (VECM) or Vector Auto-Regression(VAR).

The data for this study were obtained from secondary sources such as: research papers, policy briefs, UNCTAD Handbook of statistics, and World Development Indicators. Annual Time series data were collected for the period 1995 - 2019. The variables on which data were collected for Nigeria are: GDP growth, Poverty headcount ratio at $\$ 1.90$ a day (2011 PPP), Life expectancy at birth, and Official exchange rate (LCU per US\$, period average). Others are on Africa, and they include: intra-trade exports, intra-trade imports, and Africa total GDP.

\section{Presentation of Data and Analyses}

\subsection{Presentation of Empirical Results}

Table 1: ADF Results of Unit root Test

on Yearly Data on Variables with Trend: 1995-2019

\begin{tabular}{|l|c|c|c|c|c|}
\hline Variables & At Level & 1 $^{\text {st }}$ Difference & 2 $^{\text {nd }}$ Difference & Prob. & Order of Integration \\
\hline exrt & -0.43 & $-3.50^{* *}$ & -5.60 & 0.01 & $\mathrm{I}(1)$ \\
\hline $\mathrm{toi}_{\mathrm{t}}$ & -1.39 & $-4.15^{*}$ & -8.02 & 0.00 & $\mathrm{I}(1)$ \\
\hline $\mathrm{ph}_{\mathrm{t}}$ & -1.19 & $-5.48^{*}$ & -7.60 & 0.00 & $\mathrm{I}(1)$ \\
\hline $\mathrm{le}_{\mathrm{t}}$ & $-3.34^{*}$ & -1.18 & -1.14 & 0.02 & $\mathrm{I}(0)$ \\
\hline $\mathrm{g}_{\mathrm{t}}$ & $-2.73^{*}$ & -6.53 & -4.05 & 0.08 & $\mathrm{I}(0)$ \\
\hline
\end{tabular}


*** Significant at 10 per cent
** Significant at 5 per cent
* Significant at 1 per cent level
Critical value at 1 per cent is -3.85
Critical value at 5 per cent is -3.04
Critical value at 10 per cent is -2.66

The results of the unit root test presented above suggest that the variables except life expectancy at birth, and GDP growth rate are of order I(1). Both variables are order $\mathrm{I}(0)$.

Table 2: Johansen Co-integration - Poverty Model

Unrestricted Co-integration Rank Test (Trace)

\begin{tabular}{|l|c|c|c|c|}
\hline $\begin{array}{l}\text { Hypothesized } \\
\text { No. of CE(s) }\end{array}$ & Eigenvalue & \multicolumn{1}{c|}{$\begin{array}{c}\text { Trace } \\
\text { Statistic }\end{array}$} & $\begin{array}{c}\mathbf{0 . 0 5} \\
\text { Critical Value }\end{array}$ & Prob \\
\hline None & 0.29 & 14.33 & 29.79 & 0.82 \\
\hline At most 1 & 0.26 & 6.75 & 15.49 & 0.60 \\
\hline At most 2 & 0.00 & 0.01 & 3.84 & 0.90 \\
\hline Unrestricted Co-integration Rank Test (Maximum Eigenvalue) & Prob \\
\hline $\begin{array}{l}\text { Hypothesized } \\
\text { No. of CE(s) }\end{array}$ & Eigenvalue & $\begin{array}{c}\text { Max-Eigen } \\
\text { Statistic }\end{array}$ & $\begin{array}{c}\mathbf{0 . 0 5} \\
\text { Critical Value }\end{array}$ \\
\hline None & 0.29 & 7.57 & 21.13 & 0.92 \\
\hline At most 1 & 0.26 & 6.74 & 14.26 & 0.51 \\
\hline At most 2 & 0.00 & 0.01 & 3.84 & 0.90 \\
\hline
\end{tabular}

Source: E-View Co-integration Test Result (See Appendix)

Table 3: Johansen Co-integration - Household Welfare Model

Unrestricted Co-integration Rank Test (Trace)

\begin{tabular}{|l|c|c|c|c|}
\hline $\begin{array}{l}\text { Hypothesized } \\
\text { No. of CE(s) }\end{array}$ & Eigenvalue & \multicolumn{1}{|c|}{$\begin{array}{c}\text { Trace } \\
\text { Statistic }\end{array}$} & $\begin{array}{c}\mathbf{0 . 0 5} \\
\text { Critical Value }\end{array}$ & Prob \\
\hline None* & 0.86 & 51.66 & 29.79 & 0.00 \\
\hline At most 1 & 0.26 & 6.78 & 15.49 & 0.60 \\
\hline At most 2 & 0.00 & 0.06 & 3.84 & 0.79 \\
\hline Unrestricted Co-integration Rank Test (Maximum Eigenvalue) & Prob \\
\hline $\begin{array}{l}\text { Hypothesized } \\
\text { No. of CE(s) }\end{array}$ & Eigenvalue & $\begin{array}{c}\text { Max-Eigen } \\
\text { Statistic }\end{array}$ & $\begin{array}{c}\mathbf{0 . 0 5} \\
\text { Critical Value }\end{array}$ \\
\hline None* & 0.86 & 44.87 & 21.13 & 0.00 \\
\hline At most 1 & 0.26 & 6.72 & 14.26 & 0.52 \\
\hline At most 2 & 0.00 & 0.06 & 3.84 & 0.79 \\
\hline
\end{tabular}

Source: E-View Co-integration Test Result (See Appendix)

* Denotes rejection of the hypothesis at the 0.05 level

Table 4: Johansen Co-integration - Economic Development Model

Unrestricted Co-integration Rank Test (Trace)

\begin{tabular}{|l|c|c|c|c|}
\hline $\begin{array}{l}\text { Hypothesized } \\
\text { No. of CE(s) }\end{array}$ & Eigenvalue & $\begin{array}{c}\text { Trace } \\
\text { Statistic }\end{array}$ & $\begin{array}{c}\mathbf{0 . 0 5} \\
\text { Critical Value }\end{array}$ & Prob \\
\hline None & 0.36 & 15.40 & 29.79 & 0.75 \\
\hline At most 1 & 0.22 & 5.57 & 15.49 & 0.74 \\
\hline
\end{tabular}


Chika P. Imoagwu, Joan N. Ozoh, Chinwe M. Madueke, Chidinma C. Mbah IMPACT OF AFRICAN FREE TRADE POLICY (AGREEMENT)

ON THE SOCIO-ECONOMIC DEVELOPMENT OF NIGERIA

\begin{tabular}{|l|c|c|c|c|}
\hline \hline At most 2 & 0.00 & 0.02 & 3.84 & 0.87 \\
\hline Unrestricted Co-integration Rank Test (Maximum Eigenvalue) & \multicolumn{3}{|c|}{} \\
\hline $\begin{array}{l}\text { Hypothesized } \\
\text { No. of CE(s) }\end{array}$ & Eigenvalue & $\begin{array}{c}\text { Max-Eigen } \\
\text { Statistic }\end{array}$ & $\begin{array}{c}\mathbf{0 . 0 5} \\
\text { Critical Value }\end{array}$ & Prob \\
\hline None & 0.36 & 9.82 & 21.13 & 0.76 \\
\hline At most 1 & 0.22 & 5.55 & 14.26 & 0.67 \\
\hline At most 2 & 0.00 & 0.02 & 3.84 & 0.87 \\
\hline
\end{tabular}

Source: E-View Co-integration Test Result (See Appendix)

The results of the Johansen Co-integration tests presented above shows that the trace statistics and Maximum-Eigen statistics are less than the critical values at $5 \%$ level of significance for the poverty and economic development models. This implies that the null hypothesis will be accepted, which suggests that there is no co-integrating equation. This implies that there is no long-run causality running from exchange rate, and trade openness to poverty, and economic development. In the case of the household welfare model, the trace statistics and Maximum-Eigen statistics for the second hypothesis are less than the critical values at $5 \%$ level of significance. This means that the null hypothesis will be rejected, which indicates that there is at least one co-integrating equation. This shows that there is long-run causality running from exchange rate, and trade openness to household welfare.

Table 5: Results of Static Regression of Equation 1

Dependent Variable is pht

\begin{tabular}{|c|c|c|c|c|}
\hline Variables & Coefficients & Std. Error & t-statistic & Prob. \\
\hline exrt-1 & 0.01 & 0.02 & 0.72 & 0.48 \\
\hline exrt-2 & -0.04 & 0.03 & -1.28 & 0.21 \\
\hline toit-1 & -319192.1 & 99861303 & -0.00 & 0.99 \\
\hline toit-2 & -38508068 & 95097662 & -0.40 & 0.69 \\
\hline $\mathrm{ph}_{\mathrm{t}-1}$ & 0.68 & 0.22 & 3.04 & 0.00 \\
\hline$\overline{p h t-2}$ & -0.12 & 0.19 & -0.63 & 0.53 \\
\hline $\mathrm{C}$ & 29.32 & 13.78 & 2.12 & 0.05 \\
\hline
\end{tabular}

Source: E-View System Equation 1 (See Appendix)

Table 6: Results of Static Regression of Equation 2

Dependent Variable is let

\begin{tabular}{|c|c|c|c|c|}
\hline Variables & Coefficients & Std. Error & t-statistic & Prob. \\
\hline exrt-1 & 0.00 & 0.00 & 3.06 & 0.00 \\
\hline exrt-2 & 0.00 & 0.00 & 4.47 & 0.00 \\
\hline toit-1 & 52785.41 & 253740.7 & 0.20 & 0.83 \\
\hline toit-2 & 376617.2 & 260057.3 & 1.44 & 0.17 \\
\hline$l_{t-1}$ & 1.93 & 0.05 & 37.88 & 0.00 \\
\hline let-2 & -0.99 & 0.04 & -21.61 & 0.00 \\
\hline $\mathrm{C}$ & 0.01 & 0.00 & 3.47 & 0.00 \\
\hline
\end{tabular}

Source: E-View System Equation 2 (See Appendix) 
Table 7: Results of Static Regression of Equation 3

Dependent Variable is $g_{t}$

\begin{tabular}{|c|c|c|c|c|}
\hline Variables & Coefficients & Std. Error & t-statistic & Prob. \\
\hline exrt-1 & -0.00 & 0.03 & -0.07 & 0.94 \\
\hline exrt-2 & 0.00 & 0.04 & 0.13 & 0.89 \\
\hline toit-1 & 266000000 & 133000000 & 2.00 & 0.06 \\
\hline toit-2 & -366000000 & 126000000 & -2.91 & 0.01 \\
\hline$g_{t-1}$ & 0.30 & 0.23 & 1.26 & 0.22 \\
\hline$g_{t-2}$ & 0.19 & 0.20 & 0.96 & 0.34 \\
\hline $\mathrm{C}$ & 7.73 & 4.26 & 1.81 & 0.08 \\
\hline
\end{tabular}

Source: E-View System Equation 3 (See Appendix)

The results of the static regression analyses for the three models presented above show that the Adjusted R-Squares and the F-statistic values for model one and two very high but those of model three are low. These suggest that the overall regression for model one, and two are significant but model three is less significant.

Table 8: Results of Vector Auto Regression Estimates of Equation 1

Dependent Variable: pht

\begin{tabular}{|c|c|c|c|c|}
\hline Variables & Coefficients & Std. Error & t-statistic & Prob. \\
\hline exrt-1 & 0.01 & 0.02 & 0.72 & 0.48 \\
\hline exrt-2 & -0.04 & 0.03 & -1.28 & 0.21 \\
\hline toitt-1 & -319192.1 & 100000000 & -0.00 & $0.99 *$ \\
\hline toitt-2 & -38508068 & 95000000 & -0.40 & $0.69^{*}$ \\
\hline pht-1 & 0.68 & 0.22 & 3.04 & 0.00 \\
\hline $\mathrm{ph}_{\mathrm{t}-2}$ & -0.12 & 0.19 & -0.63 & $0.53^{*}$ \\
\hline $\mathrm{C}$ & 29.32 & 13.78 & 2.12 & 0.05 \\
\hline
\end{tabular}

Source: E-View VAR and System Equation Result (See Appendix)

* Denotes significance at 0.500

Table 9: Results of Vector Error Correction Estimates of Equation 2

Dependent Variable: let

\begin{tabular}{|c|c|c|c|c|}
\hline Variables & Coefficients & Std. Error & t-statistic & Prob. \\
\hline exrt-1 & 0.00 & 0.00 & 3.06 & 0.00 \\
\hline exrt-2 & 0.00 & 0.00 & 4.47 & 0.00 \\
\hline toitt-1 & 52785.41 & 25374.1 & 0.20 & $0.83^{*}$ \\
\hline toitt-2 & 376617.2 & 260057 & 1.44 & 0.17 \\
\hline let-1 & 1.93 & 0.05 & 37.88 & 0.00 \\
\hline let-2 & -0.99 & 0.04 & -21.61 & 0.00 \\
\hline ECM(-1) & 0.00 & 0.00 & 4.76 & 0.00 \\
\hline $\mathrm{C}$ & 0.01 & 0.00 & 3.47 & 0.00 \\
\hline
\end{tabular}

Source: E-View VEC and System Equation Result (See Appendix)

* Denotes significance at 0.500 
ON THE SOCIO-ECONOMIC DEVELOPMENT OF NIGERIA

Table 10: Results of Vector Auto Regression Estimates of Equation 3

Dependent Variable: $g_{t}$

\begin{tabular}{|c|c|c|c|c|}
\hline Variables & Coefficients & Std. Error & t-statistic & Prob. \\
\hline exrt-1 & -0.00 & 0.03 & -0.07 & $0.94^{*}$ \\
\hline exrt-2 & 0.00 & 0.04 & 0.13 & $0.89^{*}$ \\
\hline toitt-1 & 266000000 & 130000000 & 2.00 & 0.06 \\
\hline toitt-2 & -366000000 & 130000000 & -2.91 & 0.01 \\
\hline $\mathrm{g}_{\mathrm{t}-1}$ & 0.30 & 0.23 & 1.26 & 0.22 \\
\hline$g_{t-2}$ & 0.19 & 0.20 & 0.96 & 0.34 \\
\hline $\mathrm{C}$ & 7.73 & 4.26 & 1.81 & 0.08 \\
\hline
\end{tabular}

Source: E-View VAR and System Equation Result (See Appendix)

* Denotes significance at 0.500

Since the Johansen Co-integration tests show that there is no long-run causality in model one and three, Vector Autoregression (VAR) estimations were conducted while Vector Error Correction (VEC) estimation. The result for model suggests that there is significant negative relationship between trade openness in Africa and poverty headcount in Nigeria. This is an indication that the African Continental Free Trade Areas (AfCFTA) would contribute to poverty alleviation in the continent. Also, the result of model two shows that there is direct relationship between trade openness, and life expectancy at birth in Africa. However, the coefficient of the Error Correction Model (ECM) coefficient is positive and insignificant, suggesting that short-run changes in explanatory variables have no long-run effects on the life expectancy at birth. This means that al though the AfCFTA may help to improve the social welfare of households, the impact may not longlasting. The VAR result for model three is mixed. One-year lag of trade openness has positive effect on economic growth of Nigeria, but the effect of two-year lag is negative while both effects are insignificant. It could be deduced from this finding that the AfCFTA may not stimulate economic growth and development in Nigeria.

\subsection{Stimulation Results}

According to United Nations Economic Commission for Africa (UNECA), the AfCFTA is expected to increase intra-Africa trade by 15 to 25\% (Signé \& van der Ven, 2019). Based on this prediction, the models estimated in the previous analyses were simulated, with other variables held constant at their 2019 values, to know the possible impact of the between 15 to $25 \%$ increase in intra-Africa trade on the poverty headcount, life expectancy at birth, and economic growth of Nigeria 2020. The results of the scenario analysis are presented below: 
ON THE SOCIO-ECONOMIC DEVELOPMENT OF NIGERIA

Table 11: Simulation Result of Impacts of increase in intra-Africa trade on the poverty headcount, life expectancy at birth, and economic growth

\begin{tabular}{|l|c|c|c|}
\hline Expected Change in $\mathbf{2 0 2 0}$ & $\begin{array}{c}\text { Scenario A } \\
\mathbf{1 5 \%}\end{array}$ & $\begin{array}{c}\text { Scenario B } \\
\mathbf{2 0 \%}\end{array}$ & $\begin{array}{c}\text { Scenario C } \\
\mathbf{2 5 \%}\end{array}$ \\
\hline Change in poverty headcount & $+20.6 \%$ & $+20.6 \%$ & $+20.6 \%$ \\
\hline Change in life expectancy & $-11.4 \%$ & $-11.4 \%$ & $-11.4 \%$ \\
\hline Change in GDP growth rate & $+26.5 \%$ & $+43.8 \%$ & $+61.1 \%$ \\
\hline
\end{tabular}

Source: Author's computable based on simulation analyses

It is evident from the results of the simulation analysis presented in Table 11 above that the expected expansion of intra-Africa trade under the AfCFTA would lead to increase in poverty headcount, and reduction of life expectancy in Nigeria under the three scenarios considered. Besides, there is no difference in the degree of impacts of the AfCFTA on both social indicators between the three growth scenarios. However, in the case of GDP growth rate, it was observed that the AfCFTA would lead to incremental increase in the growth rate as the intra-Africa trade expands.

\subsection{Discussion of Results}

Although some of the results from the empirical analyses are mixed and conflicting, they are quite revealing. The analyses of the impact of intra-Africa trade on the socio-economic impact of Nigeria revealed that trade openness in Africa plays significant role in poverty alleviation in Nigeria. Also, it was found that trade openness in the continent has an insignificant positive impact on life expectancy at birth in Nigeria. The impact of Africa intra-trade on the economic growth and development of Nigeria is ambiguous. However, the simulation of the expected expansion of Africa intra-trade using the estimated model based on the prediction of UNECA shows that the AfCFTA would have positive economic impact on Nigeria but affect adversely the social development of the country in terms of higher poverty headcount, and life expectancy at birth.

The result of these analyses is an affirmation of Nigeria's government skepticism of the benefits of the AfCFTA to the country. The administration of president Buhari was reluctant to sign the agreement during its initial signing on $21^{\text {st }}$ March 2018 on the suspicion that it may undermine entrepreneurship and hurt industrial development. With a nominal GDP of US\$376 million, which is about $17 \%$ of Africa's GDP, Nigeria is the largest economy in the continent just ahead of South Africa. It has a population of over 200 million people, which ranks it as the most populous black nation in the country. The country has vast landscape, and blessed with enormous natural resources including oil. With all these indices, what does the AfCFTA has to offer Nigeria? It is evident from the results of the analyses made in this study that the country does not really stand to gain from the trade agreement. Although, it was found that the AfCFTA would increase the economic growth of the country, it may lead to increase in poverty, and lower life expectancy. This may be connected to the excessive exposure of local businesses to unhealthy rivals as well as the dumping of sub-standard goods in the country, which would have adverse effects on the social development of the country. There is no doubt 
the AfCFTA is an avenue for other African countries to have unrestricted access to Nigerian economy to their benefits. Although the Nigerian government has finally signed the AfCFTA on $7^{\text {th }}$ July 2019, it is yet to ratify and deposit the instrument of ratification, it is important that policy makers in the country design proactive strategies that would safeguard local industries business; and the welfare of the people in order to re ap the full benefits of AfCFTA.

\section{Summary, Conclusion and Recommendations}

\subsection{Summary of Findings}

This study was designed to examine the implications of the AfCFTA on Nigeria with focus on poverty alleviation, household welfare, and economic development. It is believed that the AfCFTA would enhance manufacturing and industrial development, tourism, intra-African cooperation, and economic transformation in Africa (Signé \& van der Ven, 2019). However, there are some reservations over what Nigeria, as the largest economy on the continent, stands to benefit from the agreement. It is on this note that this study sought to assess empirically, the likely socio-economic implications of the AfCFTA for Nigeria. The major findings of the study are highlighted below:

1) The empirical analyses show that the AfCFTA would lead to increase in the incidence of poverty in Nigeria;

2) It was found that the implementation of the AfCFTA would affect adversely the social development of Nigeria; and

3) The simulation analyses revealed that the expected expansion of Africa intra-trade under the AfCFTA would contribute to economic growth and development of Nigeria.

\subsection{Recommendations}

Based on the findings of this study, the government is implored to:

1) Protect the local industries and entrepreneurs from unhealthy competition as this may lead to less of employment and aggravate poverty;

2) Design proactive strategies that would prevent the adverse effects of AfCFTA on the social welfare of the people;

3) Engage the private sector in identifying receptive and risk sectors;

4) Should pay more attention to the development of the service sector etc.

\subsection{Conclusion}

This study is an attempt to evaluate the socio-economic implications AfCFTA on Nigeria. The AfCFTA is world's largest free trade area since the establishment of the World Trade Organization (WTO) in 1994 (Signé \& van der Ven, 2019). It was brokered by the African Union (AU) with the aim of boosting intra-Africa trade through the removal of tariffs on most goods thereby allowing free movement of commodities, goods, and services across the continent. United Nations Economic Commission for Africa (UNECA) predicted that 
successful implementation of the agreement would increase intra-Africa trade by 15 to 25\% (Signé \& van der Ven, 2019). This is in line with theoretical justification of free trade area. Both classical and modern theories advocate for free trade, which is expected to lead to increase production efficiency, improved welfare, lower poverty, and stimulate economic growth and development.

Econometric tools such as Johansen co-integration technique and Vector Error Correction Mechanism (VECM) were used to investigate the potential socio-economic implications of the AfCFTA for Nigeria. It was found that although the AfCFTA would stimulate economic growth and development, it would aggravate the poverty situation in the country, and affect adversely the social welfare of the people. These findings affirm Nigeria's government skepticism over the benefits of the AfCFTA to the country. There is no doubt the AfCFTA is an avenue for other African countries to have unrestricted access to Nigerian economy to their benefits. Therefore, it is important that policy makers in the country design proactive strategies that safeguard socio-economic status of the people.

\section{Conflict of Interest Statement}

The authors declare no conflicts of interests.

\section{About the Authors}

Imoagwu, Chika Priscilla is a lecturer in the Department of Economics, Faculty of Social Sciences, Nnamdi Azikiwe University, Awka, Anambra State, Nigeria. She hails from Afikpo South, Ebonyi State, Nigeria. She obtained her B.Sc Economics Education in University of Nigeria, Nsukka in 2007, PGD Economics in Nnamdi Azikiwe University, Awka in 2012, M.Sc Economics in Chukwuemeka Oduemegwu Ojukwu University (COOU) (formally Anambra State University), Anambra State in 2017 and PhD in Nnamdi Azikiwe University, Awka in 2019 - Date.

Joan N. Ozoh is a lecturer in the Department of Economics, Faculty of Social Sciences, Nnamdi Azikiwe University, Awka, Anambra State, Nigeria. She hails from Onitsha, Onitsha North Local Government Area, Anambra State, Nigeria. She obtained her B.Sc Economics, M.Sc Economics and PhD Economics (in view) in Nnamdi Azikiwe University, Nigeria.

Chinwe M. Madueke is a lecturer in the Department of Economics, Faculty of Social Sciences, Nnamdi Azikiwe University, Awka, Anambra State, Nigeria. She hails from Oraifite, Ekwusigo Local Government Area, Anambra State, Nigeria. She obtained her B.Sc Economics, M.Sc Economics and PhD Economics (in view) in University of Nigeria, Nsukka, Nigeria.

Chidinma C. Mbah is a lecturer in the Department of Economics, Faculty of Social Sciences, Chukwuemeka Oduemegwu Ojukwu University (COOU) (formally Anambra State University) Anambra State, Nigeria. She hails from Okpo, Anambra State, Nigeria. She obtained her B.Sc Economics, M.Sc Economics and PhD Economics (in view) in 
Chukwuemeka Oduemegwu Ojukwu University (COOU) (formally Anambra State University), Anambra State, Nigeria.

\section{References}

Awad, A. (2019). Does economic integration damage or benefit the environment? Africa's experience. Energy Policy, 132, 991-999.

Baier, S. L., Yotov, Y. V. \& Zylkin, T. (2019). On the widely differing effects of free trade agreements: Lessons from twenty years of trade integration. Journal of International Economics, 116, 206-226.

Bene, C., Lawton, R. \& Allison, E. H. (2010). Trade Matters in the Fight Against Poverty: Narratives, Perceptions, and (Lack of) Evidence in the Case of Fish Trade in Africa. World Development, 38(7), 933-954.

Bhattacharya, S. K. \& Das, G. G. (2014). Can South-South Trade Agreements Reduce Development Deficits?: An Exploration of SAARC during 1995-2008. Journal of South Asian Development, 9(3), 253-285.

Castilho, M., Menendez, M., \& Sztulman, A. (2012).Trade Liberalisation, Inequality, and Poverty in Brazilian States. World Development, 40(4), 821-835.

Dent, C. M. (2010). Freer Trade, More Regulation? Commercial Regulatory Provisions in Asia-Pacific Free Trade Agreements. Competition and change, 14(1), 48-79.

Ezeanyeji, C. I., Imoagwu, C. P. \& Ejefobihi, U. F. (2019). Entrepreneurship development and poverty reduction in Nigeria: The synergy. International Journal of Economics, Commerce and Management, VII(4), 584-599

Ezeanyeji, C. I. \& Obi, C. O. (2019). Interest rate deregulation and savings mobilization in Nigeria: An impact analysis. International Journal of Applied Research, 5(3), 186-193

Ezeanyeji, C. I. \& Ozughalu, U. M. (2014). Conceptual and theoretical issues in poverty, and a reflection on the poverty and competitive situation in Nigeria. International Journal of Economics, Commerce and Management, 2(11), 1-16.

Ha, P. V., Kompas, T., Nguyen, H. T. M., \& Long, C. H. (2017). Building a better trade model to determine local effects: A regional and inter-temporal GTAP model. Economic Modelling, 67, 102-113.

Harilal, K. N. (2012). Regional route to multilateralism: Proliferation of PTAs among developing countries and WTO negotiations. Millennial Asia, 3(1), 1-22.

Jagdambe, S. \& Mouzam, S. M. (2019). Evaluating the Trade, Revenue and Welfare Implication of Plantation Crops under ASEAN-India FTA. Journal of Asian Economic Integration, 1(2), 224-241.

Khan, M. A., Mehmood, Q., Zakaria, M. \& ul Husnain, M. I. (2018). A Household Level Analysis of the Pakistan-Malaysia Free Trade Agreement. Journal of Asian and African Studies, 53(7), 1062-1085. 
Kien, N. T. (2009). Gravity model by panel data approach: An empirical application with implications for the ASEAN Free Trade Area. ASEANEconomic Bulletin, 26(3), 266277.

Kitwiwattanachai, A., Nelson, D. \& Reed, G. (2010). Quantitative impacts of alternative East-Asia Free Trade Areas: A Computable General Equilibrium (CGE) assessment. Journal of Policy Modeling, 32, 286-301.

Kpomblekou, E. K. M. \& Wonyra, K. O. (2020). Spatial diffusion of international trade in West African Economic and Monetary Union (WAEMU). Scientific African, 7, 1-9.

Lam, T. (2015). A review of modern international trade theories. American Journal of Economics, Finance and Management, 1(6), 604-614.

Liyanaarachchi, T. S., Naranpanawa, A. \& Bandara, J. S. (2016). Impact of trade liberalisation on labour market and poverty in Sri Lanka. An integrated macromicro modelling approach. Economic Modelling, 59, 102-115.

Maurizio, B. \& Niimi, Y. (2009). Do Regional Trade Pacts Benefit the Poor? An Illustration from Dominican Republic-Central American Free Trade Agreement in Nicaragua. World Development, 37(1), 146-160.

Mold, A. (2018). The consequences of Brexit for Africa: The case of the East African Community. Journal of African Trade, 5, 1-17.

Mold, A. \& Mukwaya, R. (2016). Modelling the economic impact of the tripartite free trade area: Its implications for the economic geography of Southern, Eastern and Northern Africa. Journal of African Trade, 3, 57-84.

Pant, M. (2010). Regional Trading Arrangements and Developing Countries: Understanding the Phenomena. International Studies, 47(2-4), 187-203.

Palit, A. (2017). Mega-regional trade agreements and non-participating developing countries: Differential impacts, challenges and policy options. Competition $\mathcal{E}$ Change, 21(5), 417-434.

Perera, M. S. S. (2009). The South Asian Free Trade Area: an Analysis of Policy Options for Sri Lanka. Journal of Economic Integration, 24(3), 530-562.

Sen, S. (2010). International trade theory and policy: A review of the literature. Levy Economics Institute of Bard College working paper, 635, 1-23.

Signé, L. and van der Ven, C. (2019). Keys to success for the AfCFTA negotiations. The Africa Growth Initiative (AGI) at Brookings Policy Brief, pp. 1-12.

Siriwardanw, M. \& Yang, J. (2007). Effects of proposed Free Trade Agreement between India and Bangladesh. South Asia Economic Journal, 8(1), 21-38.

Subasat, T. (2003). What does the Heckscher-Ohlin Model contribute to international Trade theory? A critical assessment. Review of radical political economics, 35(2), 148165.

Terzea, E. R. (2016). The concept of international trade and main classical theories. SEA Practical Application of Science, 4(2), 243-247. 

distribute, transmit or adapt the article content, providing a proper, prominent and unambiguous attribution to the authors in a manner that makes clear that the materials are being reused under permission of a Creative Commons License. Views, opinions and conclusions expressed in this research article are views, opinions and conclusions of the author(s).Open Access Publishing Group and European Journal of Economic and Financial Research shall not be responsible or answerable for any loss, damage or liability caused in relation to/arising out of conflict of interests, copyright violations and inappropriate or inaccurate use of any kind content related or integrated on the research work. All the published works are meeting the Open Access Publishing requirements and can be freely accessed, shared, modified, distributed and used in educational, commercial and non-commercial purposes under a Creative Commons Attribution 4.0 International License (CC BY 4.0). 